\title{
Control or influence? Conflict or solidarity? Understanding diversity in preferences for public participation in social policy decision making
}

\author{
Rikki Dean
}

Institute of Political Science, Goethe

University Frankfurt, Frankfurt, Germany

\section{Correspondence}

Rikki Dean, Institute of Political Science,

Goethe University, 60323 Frankfurt am Main,

Germany.

E-mail: dean@soz.uni-frankfurt.de

Funding information

ESRC, Grant/Award Number: n/a PhD project

\begin{abstract}
Participatory policy making is a contested concept that can be understood in multiple ways. So how do those involved with participatory initiatives make sense of contrasting ideas of participation? What purposes and values do they associate with participatory governance? This paper reflects on a Q-method study with a range of actors, from citizen activists to senior civil servants, involved with participatory initiatives in U.K. social policy. Using principal components analysis, supplemented with data from qualitative interviews, it identifies three shared participation preferences: participation as collective decision making, participation as knowledge transfer, and participation as agonism. These preferences demonstrate significant disagreements between the key informants, particularly concerning the objectives of participation, how much power should be afforded to the public, and what motivates people to participate. Their contrasting normative orientations are used to highlight how participatory governance theory and practice frequently fails to take seriously legitimate diversity in procedural preferences. Moreover, it is argued that, despite the diversity of preferences, there is a lack of imagination about how participation can function when social relations are conflictual.
\end{abstract}

\section{KEYWORDS}

citizen engagement, democratic innovation, discursive institutionalism, procedural preferences, public participation, Q-method 


\section{1 | INTRODUCTION}

The idea of the participating citizen has become a ubiquitous feature of the policy-making process. Democratic theorists have begun to view policy and administration as the vanguard of democratization, presenting the opportunity for "a transformation of democracy as dramatic and important as the rise of mass electoral democracy in the nineteenth century" (Warren, 2009, p. 9). Participatory policy making, however, remains a polysemous concept that can be understood in multiple ways; its practice has had a multitude of ideological influences (Barnes, Newman, \& Sullivan, 2007; Bochel, Bochel, Somerville, \& Worley, 2008; Dean, 2017). This forces those who become engaged with participatory initiatives into an act of everyday philosophy. They must make sense of the diversity in conceptions of participation and what it means for their practice. Nonetheless, there is little work that directly explores the participation preferences of the public officials that commission and fund participation programs, the civil society organizations that demand or facilitate them, and the citizens that take part. What do they think are the purposes of participation? Who should be involved and how? And how do they evaluate whether participation has been effective? Analysis of the ideology of participation has not kept pace with its practice (Martin, 2009).

Understanding how these actors make sense of participation is important for a number of reasons. First, if there is to be a democratic transformation of the policy process, this will be shaped by the imagination of those driving it. As "Discursive Institutionalism" has emphasized, agents' background ideational and foreground discursive abilities are central in shaping institutions, how they change and why they persist (Schmidt, 2008). Second, recent research has found that procedural preferences matter for political behaviors (Bengtsson \& Christensen, 2016; Neblo, 2015; Webb, 2013) and appraisals of political institutions (Hibbing \& Theiss-Morse, 2001). Understanding participation preferences thus provides a lens through which to understand participatory reforms of policy institutions and their prospects for improving institutional and policy legitimacy.

This article provides a rare, in-depth account of participation preferences, exploring them at what Schmidt (2008) has termed the "programmatic level," namely, the broad frames of reference that enable those involved in participatory processes to construct a vision of participation and use it to guide their action. It reflects on a Q-method survey-a process in which participants were asked to rank a set of normative statements about participation-and qualitative interviews conducted with 34 key informants, ranging from senior civil servants to activist citizens, involved with participatory policy making in U.K. social policy. The next section of this paper outlines how existing research on procedural preferences and in the field of participatory governance has not previously addressed these programmatic level participation preferences. This is followed by a five-step explanation of the research design. Three alternative participation preferences-participation as collective decision making, knowledge transfer, and agonism-identified using principal components analysis, are then described and further elucidated with the interview data. The final sections argue that these three preferences challenge the conventional understanding of participation in social policy as either democratic, technocratic, and consumerist, as well as highlighting a significant blind-spot regarding how participatory governance can operate in the context of the polarized conflicts that are coming to dominate contemporary politics.

\section{I PREFERENCES, THEORY, AND PRACTICE}

When compared with policy preferences, procedural preferences are surprisingly underresearched. The idea that citizens have policy preferences-for instance, on the appropriate level of redistribution through taxation or the right level of immigration-is a familiar one. For many years, there have been regular, expensive, national, and crossnational surveys devoted to understanding these preferences. A presumption that citizens are more interested in the outcomes of decisions than how they are arrived at has meant procedural preferences, concerning the process by which policy decisions are made, have been subject to much less attention (Font, Wojcieszak, \& Navarro, 2015). There has, nevertheless, recently been an upturn in interest in preferences for democratic decision making, 
particularly among those inclined to a more participatory or deliberative conception of democracy. There is now a small but burgeoning literature demonstrating that, across a variety countries, citizens' preferences for democratic decision making are diverse (Bengtsson, 2012; Bengtsson \& Christensen, 2016; Dryzek \& Berejikian, 1993; Font et al., 2015; Hibbing \& Theiss-Morse, 2001; Webb, 2013).

Efforts to directly analyze procedural preferences have not yet been taken up within research on participatory governance. The aforementioned studies of preferences for democratic decision making paints in too broad brushstrokes to be helpful in this regard, generally analyzing preferences for participation-led, representative-led, or expert-led decision making, thus suggesting that all those who favor participation construct it in a similar fashion. This is unsatisfactory because the multiple ideological influences that have precipitated the growth of participation are well remarked upon. The specter of New Public Management (NPM), for instance, is often cited as a risk to the realization of genuinely democratic participatory reforms (Papadopoulos \& Warin, 2007; Parkinson, 2004; Rowe \& Shepherd, 2002). Nonetheless, although this ideological diversity frequently forms the background to discussions of participatory governance, it rarely filters into the foreground of participatory governance research. It is simply noted and set aside. So evaluation frameworks are comprised solely of participatory and/or deliberative democratic criteria, despite their authors referencing the competing imperatives driving participation (e.g., Abelson et al., 2003; Papadopoulos \& Warin, 2007).

This tendency is most readily apparent in the participation typologies that are arguably the biggest influence on participatory practice, frequently informing participation toolkits for practitioners. The two most influential are Arnstein's (1969) famous ladder of participation and Fung's (2006) more recent democracy cube. Each typifies an alternative method of classifying approaches to participation. For Arnstein, "citizen participation is a categorical term for citizen power. It is the redistribution of power..." (1969, p. 216). Her ladder ranks various types of participation from worst to best, according to the extent to which they redistribute power. Most forms of participation, consultation for example, do not match up to radical democratic ideals, thus are dismissed as "nonparticipation." Fung instead takes a pragmatist attitude, arguing there is no canonical approach to participation; it can serve multiple purposes and values (Fung, 2006, p. 66). However, the democracy cube then abstracts from these purposes and values to categorize types of participation solely according to institutional design features. Most existing participation typologies and evaluation frameworks thus do little to incorporate the potential diversity of relevant stakeholders' participation preferences; they are either rooted in one normative orientation or abstracted from such concerns.

There are some notable exceptions that have drawn on participation theory and policy documents to elaborate alternative normative approaches to participation. Barnes et al. (2007, Chapter 2) describe four different "official participation discourses" present in New Labour's attempts at public service reform in the United Kingdom, which they term empowered public, consuming public, stakeholder public, and responsible public. Dean (2017) outlines a set of more general "participation modes" that are not tied to a particular time and place. He proposes four archetypal modes of public participation in policy decisions: knowledge transfer, collective decision making, choice and voice, and arbitration and oversight. Each is associated with a different tradition in political and public administration theory, and each possesses a corresponding function that participation performs. The four modes of participation are organized on two intersecting dimensions: sociality and negotiability. The horizontal, sociality dimension concerns the extent to which the participatory space is agonistic or solidaristic, and the vertical, negotiability dimension concerns the extent to which participation is prescribed or negotiated. These theories provide a useful guide for thinking about participation preferences. However, in drawing on public documents, they are limited to the official story. They cannot tell us whether the actors involved with participation initiatives actually subscribe to these, which discourse or mode they find most compelling, or whether different kinds of actors hold different kinds of preferences. These questions can only be answered through empirical study of preferences.

Empirical research on specific participatory governance initiatives in social policy has also, at times, foregrounded the competing normative imperatives behind participation, pointing to a mixture of consumerist, democratic, and technocratic rationales underpinning tenant participation in social housing (Cairncross, Clapham, \& Goodlad, 1997; Hickman, 2006) and service-user participation in what were NHS primary care groups (Rowe \& Shepherd, 2002). Still, 
these analyses focus on classifying the initiative as consumerist, democratic, or technocratic (Cairncross et al., 1997; Hickman, 2006) or understanding preferences for a specific participatory initiative (Rowe \& Shepherd, 2002); therefore, they either do not directly analyze preferences or analyze specific "policy level" preferences, rather than the broader "programmatic level" preferences targeted by this study. Existing research on participation preferences is either very narrow (a specific participation initiative) or very broad (the entire democratic system). There is little data on the vision of participation that those involved with participatory governance bring to their practice. An understanding of the diversity of preferences in this regard would address their omission from the participation toolkits that inform practice and illuminate the prospects for participatory reforms.

\section{3 | RESEARCH DESIGN}

This research employed a Q-method survey followed by an interview to understand the participation preferences of 34 key informants involved with U.K. participatory social policy initiatives. ${ }^{1}$ Q-methodologists stress that it is best employed for clarifying alternative perspectives regarding complex, socially contested concepts (Brown, 1980; Watts \& Stenner, 2012). Q-method is thus well suited to understanding participation preferences and has been successfully employed in cognate research projects on discourses of democracy (Dryzek \& Berejikian, 1993) and interpretations of network governance (Skelcher, Sullivan, \& Jeffares, 2013). The approach has some significant strengths for understanding participation preferences. First, Q-method's rank-ordering procedure can itself be viewed as an act of everyday philosophy: this study required participants to prioritize a set of 48 normative statements about participation by sorting them onto a standardized grid. These forced choices ensure participants reflect carefully on their preferences. It is thus a more reflective process than Likert-scale surveys, which is valuable in a field where the rhetorical power of terms such as "participation" and "empowerment" can lead to unconsidered judgements. Second, this intensive procedure, supplemented by an interview, also created a much more detailed picture of each individual's preference than a traditional survey. Nevertheless, the standardized form of the "Q-sort" enabled a systematic statistical comparison of individuals' participation preferences and their reduction to a discrete set of composite, shared preferences. The approach thus combines strengths from qualitative and quantitative research, providing a rich understanding of the preferences represented in a transparent, objective data structure that can be subject to scrutiny and replication by other researchers.

There is a well-established five-step process for conducting Q-method studies (McKeown \& Thomas, 2013). Step 1 is to generate the "Q-set" of between 40 to 80 statements that participants are to sort. First, it was necessary to map the "concourse," namely, the range of opinions on participation from which the Q-set is derived. To map the discourses and concepts manifest in the debate surrounding participation in U.K. social policy, a thematic analysis was conducted of 28 documents from the academic and gray literature, which were sourced using a systematic reviewinspired procedure that attempted to identify all U.K. publications in this field between 2002 and 2012 . This generated 257 codes on four aspects of participation: its objectives, roles of the public and officials and the relationships between them, institutional practices, and evaluation criteria. Following Skelcher et al. (2013) and Dryzek and Berejikian (1993), a sampling grid was employed in order to reduce the 257 codes to an appropriately-sized Q-set, while maintaining diversity of representation. The four aspects of participation provided one dimension of this grid, and to ensure normative plurality Dean's (2017) four modes of participation provided the other, with some additional spaces for "wildcard" statements that did not correspond to one mode. This produced a Q-set of 48 statements as distributed in Table 1. Structuring the Q-set in this way enables explicit interrogation of theoretical preconceptions without prejudicing results, because the number of possible combinations allows participants to rank statements in ways that do not support the underlying theory (Brown, 1980). As such, this design provides a test of Dean's

${ }^{1} \mathrm{~A}$ full methodological protocol for this study, with sufficient detail to enable replication is freely available at http://etheses.lse.ac.uk/ 3486/1/Dean_Democratising_Bureaucracy.pdf (Chapter 2 and Appendices). 
TABLE 1 Breakdown of Q-set statements

\begin{tabular}{|c|c|c|c|c|}
\hline \multirow[b]{2}{*}{ Mode of participation } & \multicolumn{4}{|c|}{ Component of participation } \\
\hline & Objectives & Roles and relationships & Institutional practices & Evaluation criteria \\
\hline Knowledge transfer & 2 & 2 & 2 & 2 \\
\hline Collective decision making & 2 & 2 & 2 & 2 \\
\hline Choice and voice & 2 & 2 & 2 & 2 \\
\hline Arbitration and oversight & 2 & 2 & 2 & 2 \\
\hline Wildcard & 7 & 3 & 4 & 2 \\
\hline
\end{tabular}

(2017) four modes of participation. If the typology is accurate, the participation preferences should be expected to reflect the four modes, with issues of negotiability and sociality expected to be key points of contention.

Step 2 is to select and recruit the study participants. Recruitment focused on key informants, namely, individuals with first-hand knowledge, expertise, and understanding of the phenomenon under investigation (Tremblay, 1957); who have an outsized impact on how participation is instituted; and are well equipped to engage in this intensive research procedure. Key informants were purposively sampled following Bauer and Aarts' (2000) criteria for successful corpus construction. To generate heterogeneity, the sampling targeted those involved with participatory governance with different organizational affiliations in a variety of policy domains, particularly selected due to observed differences in discourses of participation within these domains. The 34 participants were relatively evenly spread across these policy domains and affiliation types (see Table 2). A short survey was used to collect other relevant information, and there is also a good spread across demographic characteristics, including sex, age, ethnicity, income, and location. A heterogeneous sample of 34 participants corresponds to the Q-method convention of recruiting samples of around 30-50 (McKeown \& Thomas, 2013, p. 32). Moreover, it is sufficient for the aims of this study, which intends to explore the variety in participation preferences, not make probabilistic statements about their distribution in the U.K. population.

Step 3 is to conduct the Q-sorts and interviews. Participants were given the set of 48 laminated cards, each containing one of the statements. Participants were then asked to perform a quick initial sort, placing these cards into three piles-agree, disagree, and neutral-based on their opinions about public participation in social policy decisions. They were then asked to rank the statements on the preset distribution grid (see Figure 1), working from the outsides of the grid-their most strongly agree and disagree statements-inwards. The interview followed directly afterwards. There was no topic guide. The Q-sort provided the overarching thematic coherence, and questions were tailored according to participants' sorting behavior and verbal responses. The only exception was the first question. To open up the process, participants were always first asked to reflect on the Q-sort and whether there was anything they would like to challenge. The full process lasted $90 \mathrm{~min}$, with participants taking on average $25-40$ min to complete the Q-sort, leaving 50-65 min for interview. Three participants were unable to meet in person, so the Q-sort was conducted online using the specialist PoetQ software (Jeffares \& Dickinson, 2016), which replicates the process described above, with the interview conducted on Skype.

Step 4 is data analysis. The Q-sort data was subject to a principal components analysis (PCA) in order to compare the similarities and differences between each participants' preference, as represented by their Q-sort, and reduce

TABLE 2 Number of participants by affiliation type and policy domain

\begin{tabular}{lcccc} 
& Public officials & Citizens or activists & Civil society & Totals \\
\hline Healthcare & 5 & 5 & 3 & 13 \\
Housing and Local Governance & 1 & 2 & 4 & 7 \\
\hline Poverty and Social Security & 6 & 4 & 4 & 14 \\
\hline Totals & 12 & 11 & 11 & 34 \\
\hline
\end{tabular}




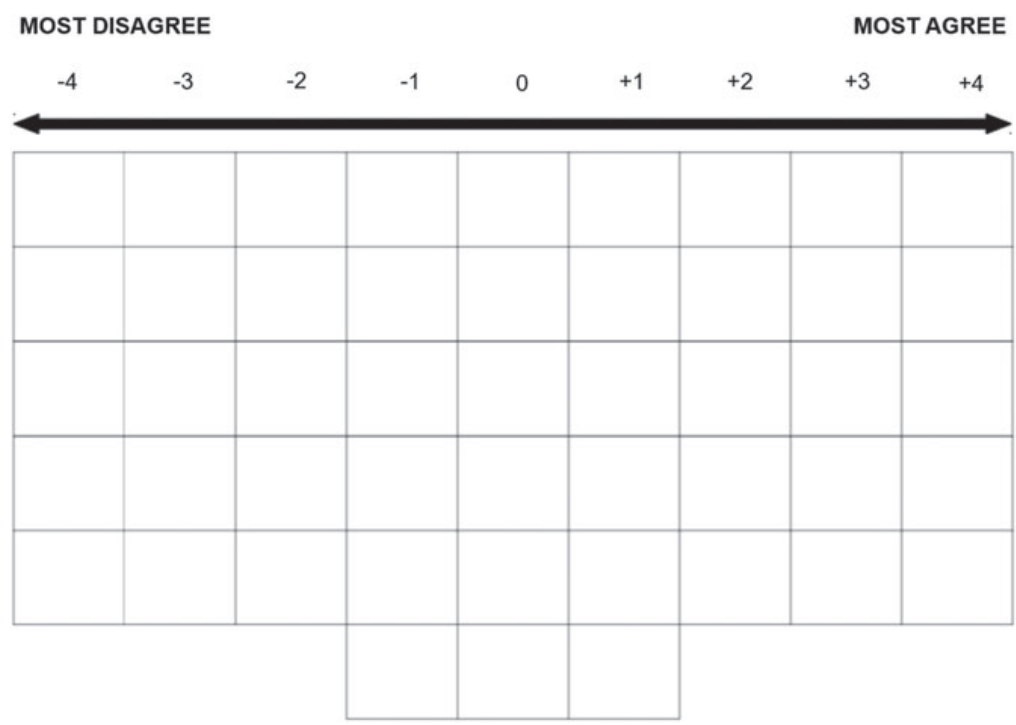

FIGURE 1 Q-sort grid

TABLE 3 Varimax-rotated three PC solution

\begin{tabular}{llll} 
& PC1 & PC2 & PC2 \\
\hline Significantly loading Q-sorts (1\% level) & 16 & 18 & 7 \\
\hline Q-sorts "flagged" for PC array & 13 & 14 & 4 \\
Variance explained by PC (\%) & 19 & 19 & 7 \\
Standard error of statement z scores & 0.14 & 0.13 & 0.24 \\
\hline
\end{tabular}

them to a smaller set of shared preferences. PCA is thus, in essence, a data reduction technique; it calculates a descriptive summary of the data through a linear transformation. Specialized Q-method software, PQMethod (Schmolck \& Anderson, 2014), was employed to extract the principal components (PCs). After a series of statistical tests $^{2}$ and using the researcher's judgement, acknowledged to have primacy (Brown, 1980; Watts \& Stenner, 2012), three PCs were retained. They were then varimax rotated to achieve a simple structure-that is, maximize each participants' loading on one PC and minimize their loadings on other PCs-so as to clearly model the different participation preferences of the participants as ideal types. This produced the solution detailed in Table 3 . Interview recordings were transcribed verbatim, then uploaded to the qualitative analysis software Nvivo. Transcripts were coded line by line, and Nvivo's Framework Analysis tool was employed to create thematic matrices in accordance with the approach outlined by Ritchie and Lewis (2003). Coding was predominantly deductive, though sensitive to inductively capturing themes not encompassed by the original codes. This produced 87 thematic codes divided among the four aspects of a participation preference: objectives of participation (22 codes), roles and relationships (22), institutional practices (21), and evaluation criteria (22).

The fifth and final step is interpretation. To interpret the PCA results, a PC array was calculated for each PC. PC arrays are calculated from the weighted average statement scores ( $z$ scores) of all "flagged" Q-sorts that significantly load onto the respective PC but are not confounded by similarly large loadings on another PC. These $z$ scores are used to create an ideal, composite Q-sort that demonstrates the distribution of statements for someone loading $100 \%$ on the PC. The PC array thus embodies the shared preference represented by the PC. The interpretations below first focus on the "characterizing" statements-those placed towards the extremes of the distribution-in order to paint a distinct picture of each shared preference. Focus then turns to the "distinguishing" statements-those with statistically significant

\footnotetext{
${ }^{2}$ Scree test, Humphrey's rule, and Kaiser-Guttman criterion.
} 
differences between PCs-to draw out the differences between preferences. The qualitative material provides a check on the validity of these interpretations and is also used to enrich the interpretations of the PC arrays through greater depth of analysis.

\section{4 | ANALYSIS 1: INTRODUCING THE THREE PARTICIPATION PREFERENCES}

\section{1 | Preference 1 (PC1)}

The shared participation preference represented by the array for PC1 (Figure 2) ${ }^{3}$ is one in which public-spirited and well-informed citizens engage in open processes of collective decision making and self-government (Statement numbers: S42, S09, S32, and S37). It is a solidaristic process oriented towards finding the common good, in which diverse publics should be brought together in a participatory space that promotes mutual respect (S11, S22, and S17). Power is an important theme. Participation should be a way for the marginalized to challenge their exclusion (S12). Moreover, policy makers should not be able to control the agenda setting, decisions, and evaluation process (S04, S43, S35, and S08); participation should transfer decision power from bureaucrats to citizens (S20). However, this is not so that citizens can pressurize and battle with self-interested authorities (S03 and S06) but in order that the two can work together as equal partners (S45). Participation is valued as a means to improve policy outcomes (S19 and S36), but it is more important that participation creates a fair decision process that realizes people's right to participate in decisions that affect them (S40, S07, and S34). The key criterion for measuring its success is whether people feel they have any influence over these decisions (S46) and the extent of control that participants wield in the process (S14). The individualistic approach to participation is rejected. Participation

\begin{tabular}{|c|c|c|c|c|c|c|c|c|}
\hline $\begin{array}{c}-4 \\
\text { (Most Disagree) }\end{array}$ & -3 & -2 & -1 & 0 & +1 & +2 & +3 & $\begin{array}{c}+4 \\
\text { (Most Agree) }\end{array}$ \\
\hline [27| Objectives] & [06 | Objectives] & [01 | Objectives] & [13| Objectives] & [26 | Objectives] & [40 | Objectives] & [07| Objectives] & [42| Roles] & [12| Objectives] \\
\hline $\begin{array}{l}\text { Empower } \\
\text { though choice }\end{array}$ & $\begin{array}{l}\text { Pressurise, hold } \\
\text { to account } \\
\text { powerful }\end{array}$ & $\begin{array}{c}\text { Develop } \\
\text { participants' } \\
\text { skills, confidence }\end{array}$ & $\begin{array}{l}\text { Access wider } \\
\text { information / } \\
\text { solutions }\end{array}$ & $\begin{array}{c}\text { Self-reliant } \\
\text { communities }\end{array}$ & $\begin{array}{l}\text { Realise right to } \\
\text { participation }\end{array}$ & $\begin{array}{c}\text { Achieve process } \\
\text { legitimacy }\end{array}$ & $\begin{array}{c}\text { Social } \\
\text { motivations for } \\
\text { participation }\end{array}$ & $\begin{array}{l}\text { Challenge } \\
\text { political / social } \\
\text { exclusion }\end{array}$ \\
\hline [33| Evaluation] & [05| Practices] & [43| Objectives] & [38 | Evaluation] & [19| Evaluation] & [25| Evaluation] & [34| Objectives] & [46 | Evaluation] & [09|Roles] \\
\hline $\begin{array}{l}\text { Resolution of } \\
\text { conflicts btw. } \\
\text { interests }\end{array}$ & $\begin{array}{c}\text { Individualised } \\
\text { channels to } \\
\text { decision-makers }\end{array}$ & $\begin{array}{c}\text { Give public voice } \\
\text { to influence } \\
\text { decision-makers }\end{array}$ & $\begin{array}{l}\text { Criteria flexible, } \\
\text { tailored to } \\
\text { purpose }\end{array}$ & $\begin{array}{l}\text { More responsive } \\
\text { policies }\end{array}$ & $\begin{array}{l}\text { Decision } \\
\text { legitimacy }\end{array}$ & $\begin{array}{l}\text { Transparency, } \\
\text { accountability \& } \\
\text { legitimacy }\end{array}$ & $\begin{array}{l}\text { Participant's } \\
\text { feelings of } \\
\text { influence }\end{array}$ & $\begin{array}{c}\text { The public as } \\
\text { experts }\end{array}$ \\
\hline [10 | Objectives] & [03 | Roles] & [41 | Objectives] & [18|Roles] & [29|Roles] & [48 | Evaluation] & [28 | Practices] & [17| Practices] & [45|Roles] \\
\hline $\begin{array}{l}\text { Competition to } \\
\text { meet public } \\
\text { needs }\end{array}$ & $\begin{array}{l}\text { Battle between } \\
\text { public and } \\
\text { institutions }\end{array}$ & $\begin{array}{l}\text { Resolve conflict } \\
\text { btw. competing } \\
\text { interests }\end{array}$ & Public reasoning & $\begin{array}{l}\text { Public as } \\
\text { overseers } \\
\text { /adjudicators }\end{array}$ & $\begin{array}{c}\text { Open exchange } \\
\text { / Greater mutual } \\
\text { understanding }\end{array}$ & $\begin{array}{l}\text { Form tailored to } \\
\text { suit situation }\end{array}$ & $\begin{array}{l}\text { Equality and } \\
\text { mutual respect }\end{array}$ & $\begin{array}{c}\text { Public \& } \\
\text { institutions as } \\
\text { equal partners }\end{array}$ \\
\hline [35 | Practices] & [15 | Practices] & [30| Roles] & [23 | Practices] & [44 | Evaluation] & [24|Practices] & [14| Evaluation] & [32 | Practices] & [37| Objectives] \\
\hline $\begin{array}{l}\text { Officials retain } \\
\text { decision power }\end{array}$ & $\begin{array}{l}\text { Promotion and } \\
\text { defence of one's } \\
\text { interest \& values }\end{array}$ & $\begin{array}{l}\text { Selected for size } \\
\text { of contribution to } \\
\text { policy outcomes }\end{array}$ & $\begin{array}{c}\text { Consensus } \\
\text { decision-making }\end{array}$ & $\begin{array}{l}\text { Representative- } \\
\text { ness of } \\
\text { participants }\end{array}$ & $\begin{array}{l}\text { Adjudication of } \\
\text { stakeholder } \\
\text { claims }\end{array}$ & $\begin{array}{l}\text { Participant } \\
\text { control of } \\
\text { process }\end{array}$ & $\begin{array}{l}\text { Open, inclusive } \\
\text { participant } \\
\text { selection }\end{array}$ & $\begin{array}{c}\text { Collective } \\
\text { decision-making } \\
\text { / self-govt. }\end{array}$ \\
\hline [08 | Evaluation] & [47| Roles] & [04 | Practices] & [39| Practices] & [02 | Practices] & [31 | Roles] & [11 | Practices] & [20 | Objectives] & [22 | Roles] \\
\hline $\begin{array}{l}\text { Sponsor/ } \\
\text { commissioner } \\
\text { satisfaction }\end{array}$ & $\begin{array}{l}\text { Public as } \\
\text { choosers }\end{array}$ & $\begin{array}{l}\text { Clearly defined } \\
\text { participatory } \\
\text { space }\end{array}$ & $\begin{array}{l}\text { Informal spaces } \\
\text { superior to } \\
\text { invited spaces }\end{array}$ & $\begin{array}{c}\text { Active } \\
\text { management of } \\
\text { the process }\end{array}$ & $\begin{array}{l}\text { Institutions / } \\
\text { officials as } \\
\text { enablers }\end{array}$ & $\begin{array}{l}\text { Oriented } \\
\text { towards the } \\
\text { common good }\end{array}$ & $\begin{array}{l}\text { Transfer power } \\
\text { from elites to } \\
\text { public }\end{array}$ & $\begin{array}{l}\text { Multiple 'publics', } \\
\text { not one 'public' }\end{array}$ \\
\hline & & & $\begin{array}{l}\text { [21 | Evaluation] } \\
\text { Participant } \\
\text { satisfaction }\end{array}$ & $\begin{array}{c}\text { [36 | Objectives] } \\
\text { Improve } \\
\text { outcomes or its } \\
\text { failed }\end{array}$ & $\begin{array}{l}\text { [16 | Practices] } \\
\text { Independence of } \\
\text { process from } \\
\text { institutions }\end{array}$ & & & \\
\hline
\end{tabular}

FIGURE 2 Preference 1 (PC1) array

\footnotetext{
${ }^{3}$ For brevity, statements are reduced to a shorthand description throughout the paper. Full statements with their PC array scores are
} available in the Supporting Information (Appendix S1). 
is not simply about promoting and defending one's own interests and values (S15), nor resolving conflicts between competing interests (S33 and S41). Similarly, collective processes of decision making are preferred to avenues for individuals to voice preferences to decision makers (S05) or choose between policy options (S47 and S27).

\section{2 | Preference 2 (PC2)}

The participation preference rendered through PC2 (Figure 3) also rejects the individualistic approach to participation (S05, S27, and S15) in favor of a vision in which public-spirited citizens engage in an effort to find the common good (S11 and S42), characterized by mutual respect and greater mutual understanding (S17 and S48). Similarly, participation is viewed not as a battle or negotiation between the state and citizens (S16, S06, and S03) but as a collaborative partnership (S31 and S45). However, the notion of participation as collective decision making and self-government is firmly rejected (S37). Participation is primarily a process in which citizens use their experiential expertise (S09) to help policy makers access wider sources of information and improve policy decisions (S13), and the key criterion for assessing whether it has been successful is to ask whether the resultant policies are more responsive to public needs and values (S19). Participation is also important in demonstrating that decision processes are fair and perceived to be legitimate (S34 and S07), and the public should feel they can influence the policies that matter to them (S46). Nonetheless, influence is not analogous to decision power; policy makers should listen to the public but also need to exercise judgement in deciding what should be taken account of in any final decision (S43). When designing participatory initiatives, it is important to have a clear question and make participants aware of the scope of the initiative and its limits regarding policy impact (S04), but there is no right way to do participation, and it is best to tailor any process to what is most appropriate to the policy issue under consideration (S11).

\section{3 | Preference 3 (PC3)}

The third and final shared participation preference (Figure 4) rejects the idea that people are motivated to participate because of bonds with others and shared social goals (S42). They are motivated to participate because

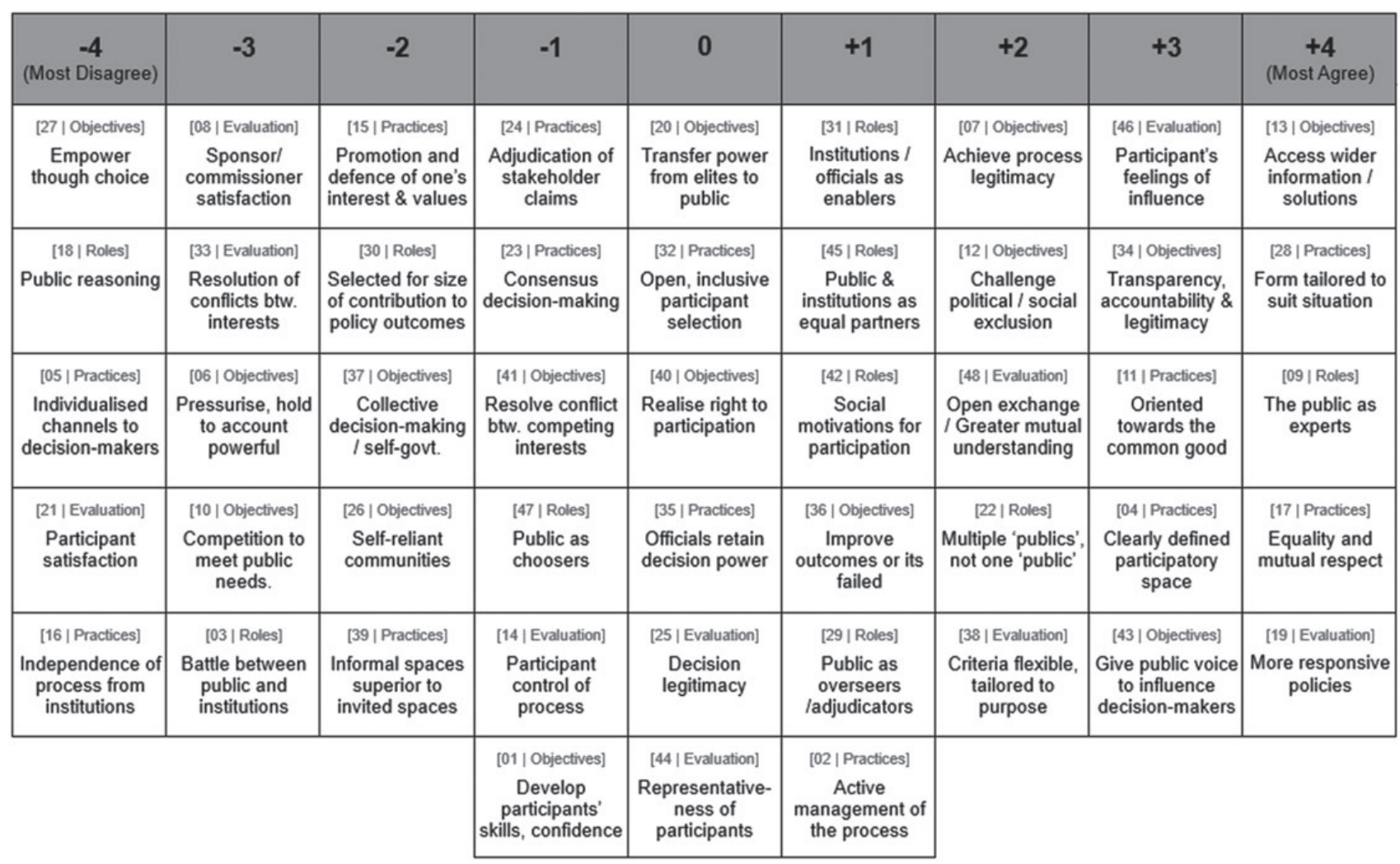

FIGURE 3 Preference 2 (PC2) array 


\begin{tabular}{|c|c|c|c|c|c|c|c|c|}
\hline $\begin{array}{c}-4 \\
\text { (Most Disagree) }\end{array}$ & -3 & -2 & -1 & 0 & +1 & +2 & +3 & $\begin{array}{c}+4 \\
\text { (Most Agree) }\end{array}$ \\
\hline [07|Objectives] & [41 | Objectives] & [06 | Objectives] & [02 | Practices] & [28| Practices] & [13|Objectives] & [09|Roles] & [39| Practices] & [22 | Roles] \\
\hline $\begin{array}{c}\text { Achieve process } \\
\text { legitimacy }\end{array}$ & $\begin{array}{c}\text { Resolve conflict } \\
\text { btw. competing } \\
\text { interests }\end{array}$ & $\begin{array}{l}\text { Pressurise, hold } \\
\text { to account } \\
\text { powerful }\end{array}$ & $\begin{array}{c}\text { Active } \\
\text { management of } \\
\text { the process }\end{array}$ & $\begin{array}{l}\text { Form tailored to } \\
\text { suit situation }\end{array}$ & $\begin{array}{l}\text { Access wider } \\
\text { information / } \\
\text { solutions }\end{array}$ & $\begin{array}{c}\text { The public as } \\
\text { experts }\end{array}$ & $\begin{array}{l}\text { Informal spaces } \\
\text { superior to } \\
\text { invited spaces }\end{array}$ & $\begin{array}{l}\text { Multiple 'publics', } \\
\text { not one 'public' }\end{array}$ \\
\hline [25 | Evaluation] & [08 | Evaluation] & [20|Objectives] & [23| Practices] & [17| Practices] & [47| Roles] & [34| Objectives] & [38 | Evaluation] & [30|Roles] \\
\hline $\begin{array}{l}\text { Decision } \\
\text { legitimacy }\end{array}$ & $\begin{array}{l}\text { Sponsorl } \\
\text { commissioner } \\
\text { satisfaction }\end{array}$ & $\begin{array}{l}\text { Transfer power } \\
\text { from elites to } \\
\text { public }\end{array}$ & $\begin{array}{c}\text { Consensus } \\
\text { decision-making }\end{array}$ & $\begin{array}{l}\text { Equality and } \\
\text { mutual respect }\end{array}$ & $\begin{array}{l}\text { Public as } \\
\text { choosers }\end{array}$ & $\begin{array}{c}\text { Transparency, } \\
\text { accountability \& } \\
\text { legitimacy }\end{array}$ & $\begin{array}{l}\text { Criteria flexible, } \\
\text { tailored to } \\
\text { purpose }\end{array}$ & $\begin{array}{l}\text { Selected for size } \\
\text { of contribution to } \\
\text { policy outcomes }\end{array}$ \\
\hline [48 | Evaluation] & [03 | Roles] & [36 | Objectives] & [21 | Evaluation] & [12| Objectives] & [05 | Practices] & [31 | Roles] & [32| Practices] & [44| Evaluation] \\
\hline $\begin{array}{l}\text { Open exchange } \\
\text { / Greater mutual } \\
\text { understanding }\end{array}$ & $\begin{array}{l}\text { Battle between } \\
\text { public and } \\
\text { institutions }\end{array}$ & $\begin{array}{c}\text { Improve } \\
\text { outcomes or its } \\
\text { failed }\end{array}$ & $\begin{array}{l}\text { Participant } \\
\text { satisfaction }\end{array}$ & $\begin{array}{c}\text { Challenge } \\
\text { political / social } \\
\text { exclusion }\end{array}$ & $\begin{array}{c}\text { Individualised } \\
\text { channels to } \\
\text { decision-makers }\end{array}$ & $\begin{array}{l}\text { Institutions / } \\
\text { officials as } \\
\text { enablers }\end{array}$ & $\begin{array}{l}\text { Open, inclusive } \\
\text { participant } \\
\text { selection }\end{array}$ & $\begin{array}{l}\text { Representative- } \\
\text { ness of } \\
\text { participants }\end{array}$ \\
\hline [42 | Roles] & [29|Roles] & [33| Evaluation] & [37| Objectives] & [10 | Objectives] & [18 | Roles] & [16|Practices] & [15| Practices] & [43| Objectives] \\
\hline $\begin{array}{c}\text { Social } \\
\text { motivations for } \\
\text { participation }\end{array}$ & $\begin{array}{l}\text { Public as } \\
\text { overseers } \\
\text { /adjudicators }\end{array}$ & $\begin{array}{l}\text { Resolution of } \\
\text { conflicts btw. } \\
\text { interests }\end{array}$ & $\begin{array}{l}\text { Collective } \\
\text { decision-making } \\
\text { / self-govt. }\end{array}$ & $\begin{array}{l}\text { Competition to } \\
\text { meet public } \\
\text { needs. }\end{array}$ & Public reasoning & $\begin{array}{c}\text { Independence of } \\
\text { process from } \\
\text { institutions }\end{array}$ & $\begin{array}{l}\text { Promotion and } \\
\text { defence of one's } \\
\text { interest \& values }\end{array}$ & $\begin{array}{l}\text { Give public voice } \\
\text { to influence } \\
\text { decision-makers }\end{array}$ \\
\hline [14| Evaluation] & [19| Evaluation] & [46 | Evaluation] & [24 | Practices] & [35| Practices] & [45 | Roles] & [27| Objectives] & [40 | Objectives] & [04 | Practices] \\
\hline \multirow[t]{3}{*}{$\begin{array}{l}\text { Participant } \\
\text { control of } \\
\text { process }\end{array}$} & $\begin{array}{c}\text { More responsive } \\
\text { policies }\end{array}$ & $\begin{array}{l}\text { Participant's } \\
\text { feelings of } \\
\text { influence }\end{array}$ & $\begin{array}{l}\text { Adjudication of } \\
\text { stakeholder } \\
\text { claims }\end{array}$ & $\begin{array}{l}\text { Officials retain } \\
\text { decision power }\end{array}$ & $\begin{array}{c}\text { Public \& } \\
\text { institutions as } \\
\text { equal partners }\end{array}$ & $\begin{array}{l}\text { Empower } \\
\text { though choice }\end{array}$ & $\begin{array}{l}\text { Realise right to } \\
\text { participation }\end{array}$ & $\begin{array}{l}\text { Clearly defined } \\
\text { participatory } \\
\text { space }\end{array}$ \\
\hline & & & [26 | Objectives] & [01 | Objectives] & [11 | Practices] & & & \\
\hline & & & $\begin{array}{l}\text { Self-reliant } \\
\text { communities }\end{array}$ & $\begin{array}{c}\text { Develop } \\
\text { participants' } \\
\text { skills, confidence }\end{array}$ & $\begin{array}{l}\text { Oriented } \\
\text { towards the } \\
\text { common good }\end{array}$ & & & \\
\hline
\end{tabular}

FIGURE 4 Preference 3 (PC3) array

they believe they have something to lose or gain, so participation should enable them to defend their interests and values (S15). There is no one general interest. Participation is about bringing together a range of different publics all with their own interests and values (S22). The purpose of this is not to have an open and honest exchange of ideas that results in greater mutual understanding (S48), nor to use the participation itself to resolve the competing interests (S41). It is about giving all relevant interests a voice that can influence the policy makers that take decisions (S43). There is qualified support for individualized mechanisms of participation such as choice to empower individuals (S27, S47, and S05). In evaluating participation then, it is more important that that all interests have been genuinely represented (S44) than that participants have had control over the process (S14), though it is important to be flexible regarding evaluation criteria, which should be tailored to the purpose of the process (S38). Participation processes should be open to all, with extra resources focused on encouraging disadvantaged groups to participate (S32), and it is important that government and public service organizations work closely with existing community organizations rather than imposing new participatory structures (S39). Nonetheless, there needs to be clear definition of the scope of the agenda and what is expected of participants (SO4).

\section{5 | ANALYSIS 2: COMPARING THE PREFERENCES}

In presenting the three participation preferences above, each was taken in isolation. This section compares the three preferences with one another to further illuminate their interpretation. Figure 5 plots statement-by-statement $z$ scores, providing an overview of how each statement was rated for each of the three preferences. The main differences are then elaborated in prose, using material from the interviews. First, Preference 1 is compared with Preference 2, then Preference 3 with the other two simultaneously. All of the differences discussed are statistically significant at the $1 \%$ level. 


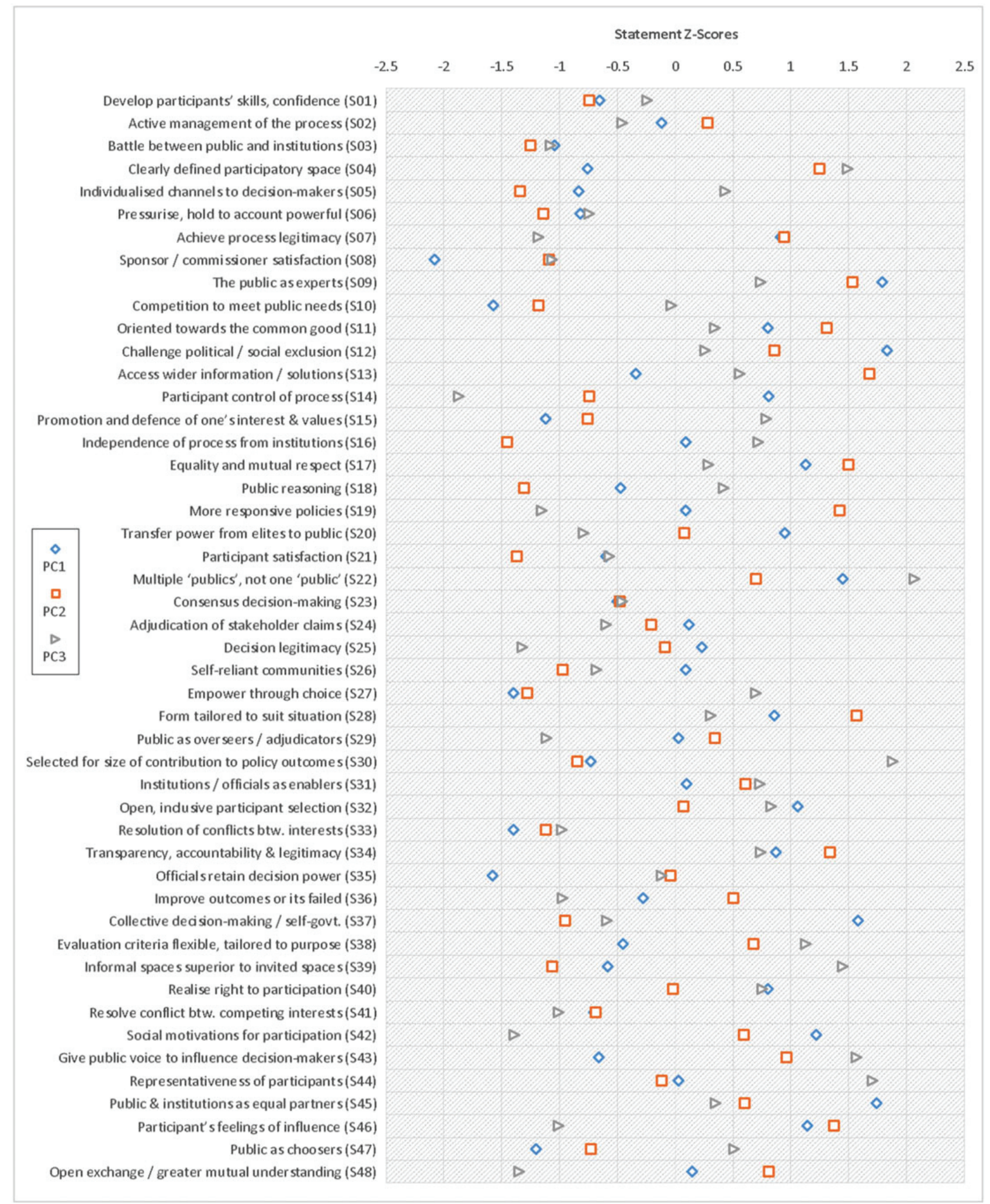

FIGURE 5 Comparison of statement $z$ scores [Colour figure can be viewed at wileyonlinelibrary.com]

\section{1 | Comparing Preference 1 and Preference 2}

Preference 1 and Preference 2 both present a direct challenge to the view of participation encapsulated by the other. The two statements with the biggest differences in z scores, S37 and S13, both capture a key idea for one of the preferences that is rejected by the other preference. The notion that participation is about realizing collective self-government through collective discussion and decision making (S37) that animates Preference 1 is rejected by 
Preference 2. Likewise, the idea that participation is about public officials accessing wider sources of information in order to improve their policy decisions (S13), which is the key objective for Preference 1, is rejected by Preference 2. These statistical results appear to capture genuine differences in opinion that were also manifest in the qualitative interviews:

I don't necessarily think that public participation in the sense of getting people to form self-governing communities is very realistic, I think it sounds quite utopian... But talking about going out and consulting people on, you know, very definite things that matter to them now, I think that's really valuable. So I think that would be the sort of public participation I quite like. (P05: Gary, PC1 = -0.29/ $P C 2=0.50 * / P C 3=0.01)^{4}$

It's not giving about giving a voice to influence decisions. It's bigger than that. And it's not about them [policy-makers] then using it make their decisions. It has to be about taking the control off of the decisions. (P28: Sarah, PC1 $=0.73 * / P C 2=0.19 / P C 3=-0.09)$

The majority of the most prominent differences between the two preferences relate to the control and power that participants should wield over the process, particularly the decision-making aspect. Whereas Preference 1 views participation as a means to transfer power (S14 and S20), Preference 2 is in favor of public officials retaining decision power (S43). Preference 2 is in favor of a tightly defined process with a specified agenda (S04), whereas Preference 1 opts for open processes in which there is participant control over the agenda (S14 and S32). In contrast, both preferences are united in their support for solidaristic statements. Statements about mutual understanding (S48), mutual respect (S17), social motivations (S42), and the common good (S11) are all positively ranked within the PC arrays for both preferences. The two preferences also show a similar level of agreement in disavowing statements that express individualistic (S15 and S05) or agonistic sentiment (S33, S03, and S06), which receive strong negative rankings for both preferences.

\section{2 | Comparing Preference 3}

Preference 3 is complex and appears to draw together two perspectives with a common element. As such, comparing the differences between Preference 3 and the other two preferences is particularly valuable in highlighting this common element. Preference 3 inverts the ratings of the other two preferences regarding people's motivation to participate. People are motivated to participate because they feel they have something to lose or gain (S15), not because of shared social goals and bonds with others (S42). That participation should aim to achieve greater mutual understanding (S48) is rejected, and ideas of equality and mutual respect are of little importance (S17). Individualized avenues of participation for citizens and groups to represent their interests and values to policy makers are more acceptable than for the other two preferences (S05 and S15), and while there is not strong support, there is less antipathy towards ideas of choice and competition (S27 and S10).

This rejection of the solidaristic nature of the other two preferences appears to come from two directions. On the one hand, there are disillusioned idealists like Carly (PC1 $\left.=0.47 / \mathrm{PC} 2=-0.13 / \mathrm{PC} 3=0.52^{*}\right)$. They believe in a more equal and participatory society but are skeptical of the motivations of policy makers and the public, along with the possibility of participation to overturn entrenched power relationships. The view was particularly characterized by a strong distrust of policy makers:

\footnotetext{
${ }^{4}$ To protect participants' anonymity, pseudonyms are used in place of real names. Figures are participants' PC loadings. They show how closely an individual's sort corresponds to the respective PC array. A score of 1.00 signifies an exact match and -1.00 an exact inversion. * marks that a sort was flagged for inclusion in the calculation of the particular PC array. The cutoff for statistical significance is 0.37 at the $1 \%$ level and 0.28 at the $5 \%$ level. PC loadings for every participant are available in the Supporting Information (Appendix S2). The participant numbers (e.g., P05) are for ease of reference with this appendix.
} 
if there was, "Right, go in this room and talk to politicians about this." You wouldn't trust them ... people just won't go in. Because they'll think, "Well why should we go in and say this, because they're not going to listen to us or take us seriously anyway." (P26: Carly)

On the other hand, there are those like Jason (PC1 $\left.=-0.25 / \mathrm{PC} 2=0.27 / \mathrm{PC} 3=0.65^{*}\right)$ who do not share this distrust of public officials and politicians but take a more pluralist line on why politicians should retain decision power. The state is viewed as neutral arbiter between conflicting interests: "That is the function that one wants the experts in local authorities and central government to fulfil, is to compare the interests" (P08: Jason). The salience of pluralist thinking to Preference 3 is also reinforced by the strong negative loading of Lucy $(P C 1=0.11 / P C 2=0.13 /$ PC3 $=-0.57^{*}$ ), who expressed explicitly antipluralist sentiment, rejecting one statement as "pluralist nonsense" and later commenting "I just think that pluralist model is slightly broken" (P10: Lucy).

\section{I DISCUSSION 1: SITUATING THE THREE PREFERENCES}

The three preferences have a clear resonance with Dean's (2017) four modes of participation-knowledge transfer, collective decision making, choice and voice, and arbitration and oversight-which informed the study design. Yet how do three preferences go into four modes? To connect the preferences back to theoretical debates about participation, this section situates the three preferences in relation to the four modes, before mapping them onto Dean's (2017) typology (Figure 6).

\section{1 | Preference 1, participation as collective decision making}

Preference 1 clearly mirrors the Collective Decision-Making mode of participation. The two share a concern for a more equal distribution of power that enables collective self-government through shared agenda-setting and decision making. Dean (2017) primarily situates the Collective Decision-Making mode in relation to the principles of participatory democracy, and the qualitative data from this research indicates a similar undercurrent of participatory democratic thinking informs Preference 1:

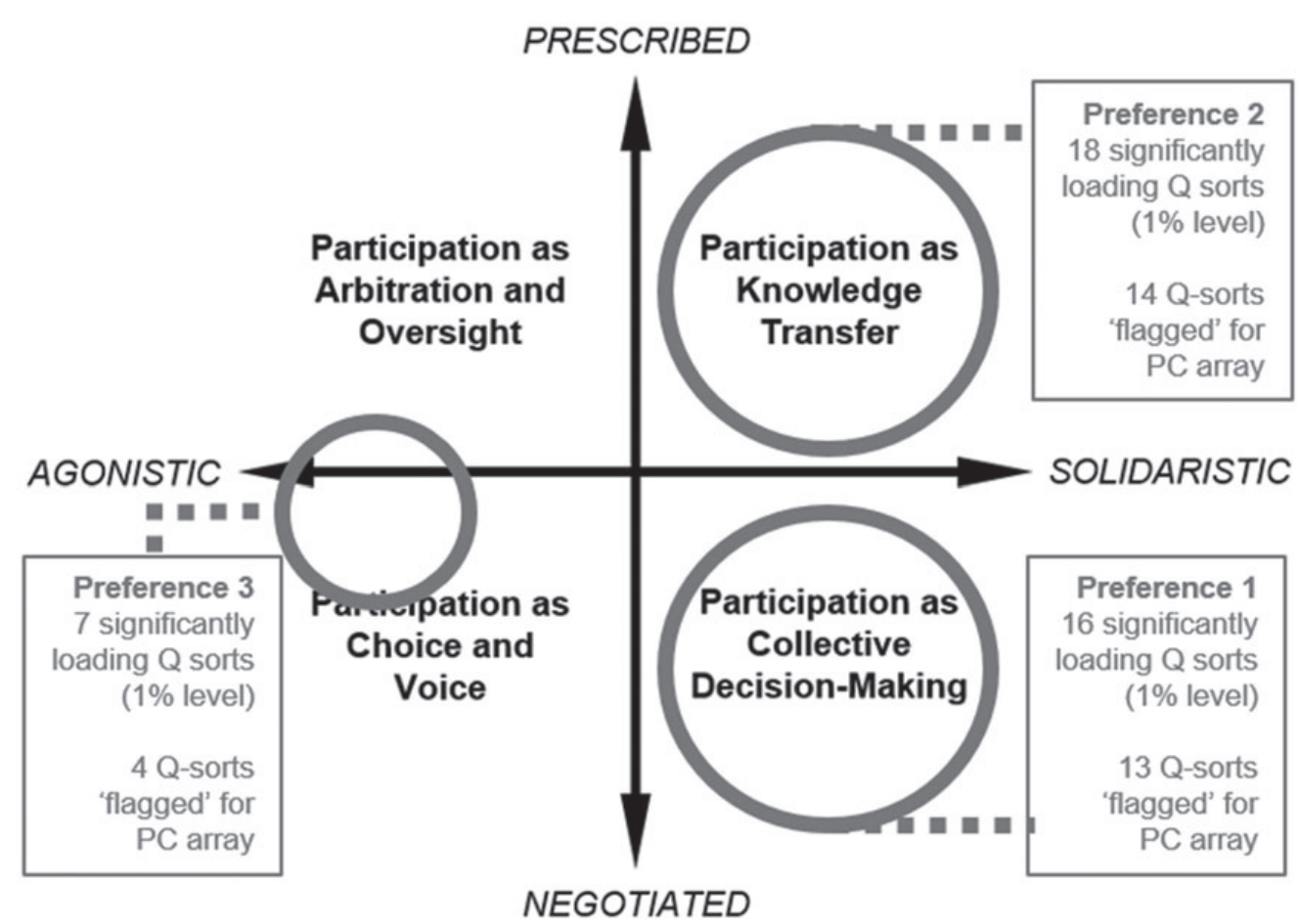

FIGURE 6 The three preferences mapped 
I think in an ideal world you would, I think you would have a much more democratic world, and I could envisage a more democratic world, where people are perfectly capable of making useful collective decisions about roads, how we live, where the money goes and so on. (P04: Flora, PC1 = 0.51*/ $P C 2=0.38 / P C 3=0.40)$

Even participation initiatives that may not fully realize participatory democratic ideals could be viewed as a useful staging post on the route towards a more participatory society, "So there's maybe in those situations, you're going down a much more service user involvement road on our way to participatory democracy" (P25: Felicity, PC1 = 0.73*/ PC2 $=0.34 / P C 3=-0.25)$.

A community development approach was, however, just as prevalent as participatory democratic thinking in underpinning these participants' preferences. Sarah (PC1 $=0.73 * / P C 2=0.19 / P C 3=-0.09)$, for instance, described her approach to participation as "classic community development":

What I would describe it as is, basically lighting fires all over the place ... You just ignite people, and you find the people in the community who want to do something, and just get the bellows out and encourage them to do it, and get them together to do it ... Classic community development. That's all it is. At its base. Community development. (P28: Sarah)

Participants also referred to approaches such as "Asset-Based Community Development" and "Appreciative Inquiry" that focus on citizen-led interventions that generate improvement through focusing on community assets or what is working well for service users and building upon it. These ideas are, however, absent from Dean's (2017) account of the Collective Decision-Making mode of participation.

This combination of ideas from participatory democracy and community development helps to explain some of the more surprising results for Preference 1. For example, consensus decision making, usually considered a cornerstone of participatory democracy, did not receive much support (S23). However, this is consistent with the community development approach, which, as can be seen from Sarah's comments, is more concerned with the continual creation of small-scale, action-oriented task-groups, than the type of generalized, collective will-formation processes typically associated with participatory democracy. Though it remains closely aligned with the Collective DecisionMaking mode of participation, Preference 1 therefore contains an important modification. It represents an understanding of participation as a solidaristic process, in which equal partners collaborate to arrive at decisions and/or take actions that benefit the common good.

\section{2 | Preference 2, participation as knowledge transfer}

Preference 2 even more closely aligns to one of Dean's (2017) four modes of participation. The focus on capturing lay expertise to inform better policy decisions by officials is redolent of the Knowledge Transfer mode. The reasons participants gave for why the public was invited to contribute their expertise and opinions but not tasked with making the decisions further reinforce this connection. Within the Knowledge Transfer mode, the public is valued for its experiential expertise, but public officials retain a monopoly on rational judgement. Likewise, those who hold Preference 2 saw public officials as more capable of taking decisions, as trained to reflect on their own biases, integrate multiple sources of potentially conflicting information, and take a view on the bigger picture:

I think that that's why we have public officials or publicly elected kind of posts, is to sort of step back and look at the bigger picture and hopefully have access to all the information necessary to make a decision which the people in the participation thing might not have. (P07: Celia, PC1 $=0.23 / P C 2=0.64^{*}$ ) PC3 $=-0.08)$

In addition, they were viewed as connected into the broader policy system so more capable of knowing which decisions would result in tractable interventions, "we [the local authority] are policy experts, we know more than they do 
about the actual policy levers at our disposal to actually make change" (P01: Mark, PC1 $=0.15 / \mathrm{PC} 2=0.70 * /$ PC3 $=-0.04)$.

The Knowledge Transfer mode is situated in relation to the Westminster model of government, in which impartial public servants take their cue from politicians (Dean, 2017, p. 218). The reluctance to transfer decision power away from public officials and politicians was similarly related to support for the primacy of electoral democracy. Elected officials set the broad agenda, and the public have their input at the ballot box, so participation initiatives have to take their cue from this,

I think your election, your democratic mandate, is almost where you're going to target and what you're going to focus on. Actually how you're going to do it, that's where you have participation. (P01: Mark)

For civil servants, this was also a factor in the need to clearly specify the agenda and parameters of participatory processes. Because politics restricts their own agenda-setting capacity, honesty about the limits of participation is necessary to maintain trust and avoid frustration.

Participation was also more broadly viewed as a means to rebuild a broken relationship between public and officials. However, it was not conceived as a way of keeping self-interested officials in check but as a means to dispel unwarranted public distrust by demonstrating officials genuinely do work in the public interest. Again, this is framed in Knowledge Transfer terms, as an exchange of information between public-spirited governors and those they govern. As such, Preference 2 provides a strong indication that the Knowledge Transfer mode of participation is a prevalent way of thinking among those involved in participatory governance activities.

\section{3 | Preference 3, participation as agonism}

Preference 3 does not straightforwardly reflect one of the remaining two modes of participation: Choice and Voice or Arbitration and Oversight. There is an affinity in that the pluralist idea of participation as interest representation informs both Preference 3 and these two modes of participation. In addition, there was an implicit understanding of participation as consumer voice. Jason, for instance, spoke extensively about how he would use focus groups to test policy concepts with those who would be affected by them,

And then you listen to what they tell you. And what they tell you, what you're not necessarily doing, is a quantitative study into how many people like and how many people dislike your policy idea. What you're trying to do is get a handle on whether your policy concept is solving the real problem or the real issue that they experience. (P08: Jason, PC1 $=-0.25 /$ PC2 $\left.=0.27 / P C 3=0.65^{*}\right)$

Here, participation is viewed as analogous to market research, where civil servants design policy products then test whether they meet the needs of policy consumers. Nonetheless, it cannot be claimed that Preference 3 represents a Choice and Voice approach to participation; the Q-sort data show only moderate support for these ideas.

Arbitration and Oversight statements were, on average, even more negatively ranked for Preference 3 than for the other two preferences. There is thus little relation to this mode, despite each's connection to pluralist ideas. Accordingly, Preference 3 provides simultaneously some support and a significant challenge to the typology of participation modes. As an agonistic counterpoint to the solidarism of Preferences 1 and 2, it further demonstrates the usefulness of the typology's dimensions in predicting the major cleavages between different participation preferences. However, this agonistic sentiment does not directly translate into one of the two agonistic modes of participation.

Should the Choice and Voice and Arbitration and Oversight modes of participation be jettisoned in favor of Preference 3's more generalized conception of Participation as Agonism? That would be a hasty move. Unlike the other two preferences, Preference 3 is based on the responses of only a small number of participants (see Figure 6). As such, more research is needed to establish the robustness of this finding. Moreover, Preference 3 does not appear to provide a comprehensive and coherent approach of how to do agonistic participation, because it captures the 
common agonistic sentiment of a small number of participants, whose preferences are opposed on other matters. It was described above, for instance, how Jason believed citizens could represent their interests to officials for impartial judgement, whereas as Carly had little trust in officials impartiality. The value of Preference 3, then, is not in elaborating a new approach to agonistic participation. Its value is in demonstrating that there is significant skepticism regarding the predominant solidaristic model of participatory governance but that these skeptics have not fully developed an alternative agonistic approach. This is perhaps no surprise given the neglect of agonistic approaches to participation in the academic and policy literature. Accordingly, the Choice and Voice and Arbitration and Oversight modes may remain useful for expanding our participatory imagination to encompass agonistic practices.

In summary, though there is not an exact match between the three preferences and Dean's (2017) four modes of participation, the empirical findings provide relatively strong support for the theoretical typology. As Figure 6 summarizes, the two dimensions of the typology are predictive of the major differences between preferences, and the two most prominent preferences precisely mirror the Knowledge Transfer and Collective Decision-Making modes.

\section{7 | DISCUSSION 2: IMPLICATIONS OF THE PREFERENCES}

The identification of these three alternative preferences for participation mirrors the finding from the broader procedural preference literature that citizens have diverse preferences about democratic decision making (Bengtsson, 2012; Dryzek \& Berejikian, 1993; Font et al., 2015). Though the analysis operates on a different level of preferences, the findings also contribute some insights to this literature. The identification of the Knowledge Transfer perspective on participation helps make sense of something that has previously been presented as an incongruous finding, that support for citizen engagement is compatible with a preference for decision making by experts (Bengtsson, 2012; Font et al., 2015). The findings also contribute to the debate around "stealth" versus "sunshine" conceptions of democracy. This debate revolves around whether citizens have a preference for leaving decisions to elites but are mobilized to participate out of distrust for, or dissatisfaction with, contemporary institutions (Hibbing \& Theiss-Morse, 2002) or whether they have a preference for participation but are demobilized by their negative feelings about the status quo (Neblo, 2015). The discovery that most of the participants, both official and civil society actors, preferred to engage in solidaristic relations provides a potential explanation for Neblo's (2015) "sunnier" finding that people's willingness to participate in deliberative politics increases along with an increase in positive perceptions of institutions.

The three preferences challenge the ways participation in social policy is usually categorized. They do not neatly correspond to the democratic, technocratic, and consumerist distinction frequently applied to contrasting ideas of participation (Cairncross et al., 1997; Hickman, 2006; Martin, 2009). One might make the case that Preference 1 is the democratic approach and Preference 2 the technocratic; however, the division between them was just as much about competing conceptions of democracy: participatory versus representative. To label them as "democratic" and "technocratic" would therefore conceal an important point of contention. Moreover, it would carry a highly contestable value judgement about what is the more democratic form of democracy.

There is surprisingly no obvious NPM approach among the preferences. The rise of participatory governance has often been attributed to a challenge from left and right to classical notions of public administration. Rowe and Shepherd (2002) even claim that NPM conceptions of participation were hegemonic among the members of NHS Primary Care Group Boards. While this research did not find an NPM approach, Preference 2 was situated within the Westminster model and classical public administration ideas of the expert, public-spirited bureaucrat. This suggests that analysis of the drivers of participatory governance has overplayed the role of NPM and underestimated the extent to which old ways of governing can incorporate new ideas. The primary cleavage between those involved with participation initiatives appears to be between a participatory democratic and a Westminster model approach, not a participatory democratic and NPM approach.

The demonstrable evidence of alternative normative preferences for participation is a significant challenge to the notion that "citizen participation is a categorical term for citizen power," and anything less is "tokenism" or 
"nonparticipation" (Arnstein, 1969). Around half the participants in this study rejected this view; they saw participation more as a means to broaden the inputs into policy decisions, rather than redistribute power to citizens. It may be tempting to view this as a cynical attempt by public officials to justify their privilege and power-what Pearce (2010, p. 15) has called the appropriation of the discourses and concepts of participation in order to turn them into new tyrannies. Nevertheless, this would be a significant oversimplification. Though a preponderance of civil society and activist participants had their highest loading on Preference 1, and civil servant participants on Preference 2, more than a third of participants confound this mold. Participatory governance theory needs to take seriously the idea of competing normative orientations to participation and recognize that even good faith attempts at participation are likely to be subject to normative contestation.

\section{8 | CONCLUSION}

This research used Q-method to engage key actors in U.K. participatory social policy in an act of everyday philosophy. This approach enabled the combination of quantitative and qualitative data to furnish a rare, in-depth account of the alternative purposes and values associated with different preferences for participatory governance. The three participation preferences identified-respectively termed, participation as collective decision making, knowledge transfer, and agonism-demonstrate significant differences between these key informants' perspectives on the purposes of participation, what motivates people to participate, and how much power should be afforded to the public.

These three preferences challenge a number of conceptual categories in the participatory governance literature, for instance, that approaches to participation are straightforwardly either democratic, technocratic, or consumerist (Cairncross et al., 1997; Hickman, 2006; Martin, 2009); that an NPM perspective on participation is hegemonic among policy makers (Rowe \& Shepherd, 2002); and that any diversion from participatory democratic ideals is simply "inauthentic participation" (Arnstein, 1969; Pearce, 2010). The findings provide empirical support for Dean's (2017) theoretical modes of participation and contention that we must take seriously alternative normative orientations to participation.

Taking account of diverse participation preferences could also improve the participation toolkits used by policy makers and practitioners, which are often lacking in this regard. Arnstein's ladder has been influential over practitioner frameworks; for instance, NHS England and the International Association of Public Participation use amended versions of it. These adaptations temper Arnstein's strong normative orientation behind a surface pragmatism, "activity on every step of the ladder is valuable, although participation becomes more meaningful at the top of the ladder" (NHS England, 2015, p. 14), yet this conceals how the commitment to participatory democracy informs the ladder. The ladder makes sense for Arnstein precisely because it is a proposition about what to do: aim for citizen control. The Knowledge Transfer preference indicates the problem with these toolkits. Those who hold it do not view citizen control as a superior form of participation to consultation. They value consultation but see citizen control as compromised by a lack of accountability and decision-making expertise. A framework that takes the normative case for "progressing" up the ladder as self-evident is unlikely to convince them to move on from consultation. Neither is it likely to help them do consultation better.

This points to a further application of the detailed information about preferences provided by this work: it is useful in making one's proposition for a participation initiative compelling to those with different preferences, because it is better to address your opponents' actual position, rather than an inaccurately imagined alternative. A valuable insight for those who would like to realize more radically democratic institutional reforms is that, if they want to make allies of those who favor participation as knowledge transfer, then arguments about empowerment and citizen control are unlikely to prove persuasive. They will need to address them with convincing practical propositions that allay fears about democratic accountability and emphasize the epistemic benefits of participation.

If policy actors' preferences are useful in understanding institutional change (Schmidt, 2008), what participatory reforms should be expected based on the three preferences? The key informants were principally divided between 
Preference 1, Collective Decision Making and Preference 2, Knowledge Transfer. As these appear to be the dominant conceptions of participation among key informants, participatory institutional reforms will commonly be framed in these terms, as opportunities for greater citizen involvement in decision making or for harnessing citizen expertise to improve policies. Both approaches are overtly solidaristic, concerned with working collaboratively to identify and administer the collective interest. With the overwhelming majority of participants holding a preference for solidaristic forms of participation, there were few ideas for how participatory policy making should operate when agonistic social relations prevail. This is compounded by the finding that even those who espouse agonistic sentiment do not translate this into a coherent proposal for agonistic participatory governance. These preferences suggest the likelihood of agonistic participatory reforms is therefore small. In a political context that is increasingly polarized and populist, in which contemporary society has been described as a "society of generalized distrust" (Rosanvallon, 2008, p. 11), a much greater awareness of how participatory governance can be effective in these conditions is necessary in order for it to remain relevant and offer potential solutions to the current challenges facing democratic institutions.

\section{ACKNOWLEDGMENTS}

I am indebted to all the people who made this research possible by giving up 90 min of their time to answer my impossible questions about participation, as well as all the people who helped in recruiting this diverse set of participants. I am grateful to Tania Burchardt, Maija Jäske, Michael MacKenzie, Quinton Mayne, and two reviewers for their detailed comments on earlier versions of this paper and to the ESRC for funding the research.

\section{ORCID}

Rikki Dean (10 http://orcid.org/0000-0001-5381-4532

\section{REFERENCES}

Abelson, J., Forest, P.-G., Eyles, J., Smith, P., Martin, E., \& Gauvin, F. (2003). Deliberations about deliberative methods. Social Science \& Medicine, 57(2), 239-251.

Arnstein, S. R. (1969). A ladder of citizen participation. Journal of the American Institute of Planners, 35(4), $216-224$.

Barnes, M., Newman, J., \& Sullivan, H. (2007). Power, participation and political renewal. Bristol: Policy Press.

Bauer, M. W., \& Aarts, B. (2000). Corpus construction. In M. W. Bauer, \& G. Gaskell (Eds.), Qualitative researching with text, image and sound. London: Sage Publications.

Bengtsson, Å. (2012). Citizens' perceptions of political processes. Revista Internacional de Sociología, 70(2), 45-64.

Bengtsson, Å., \& Christensen, H. (2016). Ideals and actions: Do citizens' patterns of political participation correspond to their conceptions of democracy? Government and Opposition, 51(2), 234-260.

Bochel, C., Bochel, H., Somerville, P., \& Worley, C. (2008). Marginalised or enabled voices? 'User participation' in policy and practice. Social Policy and Society, 7(2), 201-210.

Brown, S. (1980). Political subjectivity. London: Yale University Press.

Cairncross, L., Clapham, D., \& Goodlad, R. (1997). Housing management, consumers, and citizens. London: Routlege.

Dean, R. J. (2017). Beyond radicalism and resignation: The competing logics of public participation in policy decisions. Policy \& Politics, 45(2), 213-230.

Dryzek, J. S., \& Berejikian, J. (1993). Reconstructive democratic theory. The American Political Science Review, 87(1), 48-60.

Font, J., Wojcieszak, M., \& Navarro, C. J. (2015). Participation, representation and expertise: Citizen preferences for political decision-making processes. Political Studies, 63(S1), 153-172.

Fung, A. (2006). Varieties of participation in complex governance. Public Administration Review, 66, 66-75.

Hibbing, J. R., \& Theiss-Morse, E. (2001). Process preferences and American politics. The American Political Science Review, 95(1), 145-153.

Hibbing, J. R., \& Theiss-Morse, E. (2002). Stealth democracy. New York: Cambridge University Press.

Hickman, P. (2006). Approaches to tenant participation in the English local authority sector. Housing Studies, 21(2), 209-225. 
Jeffares, S., \& Dickinson, H. (2016). Evaluating collaboration: The creation of an online tool employing Q methodology. Evaluation, 22(1), 91-107.

Martin, G. P. (2009). Public and user participation in public service delivery. Sociology Compass, 3(2), 310-326.

McKeown, B., \& Thomas, D. (2013). Q methodology. London: SAGE.

Neblo, M. A. (2015). Deliberative democracy between theory and practice. Cambridge: Cambridge University Press.

NHS England (2015). Patient and public participation policy. Available from: https://www.england.nhs.uk/wp-content/ uploads/2015/11/ppp-policy.pdf (accessed 10 May 2016).

Papadopoulos, Y., \& Warin, P. (2007). Are innovative, participatory and deliberative procedures in policy making democratic and effective? European Journal of Political Research, 46(4), 445-472.

Parkinson, J. (2004). Why deliberate? The encounter between deliberation and new public managers. Public Administration, 82(2), 377-395.

Pearce, J. (2010). Participation and democracy in the twenty-first century city. Basingstoke: Palgrave Macmillan.

Ritchie, J., \& Lewis, J. (2003). Qualitative research practice. London: SAGE.

Rosanvallon, P. (2008). Counter-democracy. Cambridge: Cambridge University Press.

Rowe, R., \& Shepherd, M. (2002). Public participation in the new NHS: No closer to citizen control. Social Policy \& Administration, 36(3), 275-290.

Schmidt, V. A. (2008). Discursive institutionalism. Annual Review of Political Science, 11(1), 303-326.

Schmolck P. and Anderson J. (2014) PQMethod. Available from: http://schmolck.userweb.mwn.de/qmethod/.

Skelcher, C., Sullivan, H., \& Jeffares, S. (2013). Hybrid governance in European citiesPalgrave Macmillan.

Tremblay, M. A. (1957). The key informant technique. American Anthropologist, 59(4), 688-701.

Warren, M. E. (2009). Governance-driven democratization. Critical Policy Studies, 3(1), 3-13.

Watts, S., \& Stenner, P. (2012). Doing Q methodological research. London: SAGE.

Webb, P. (2013). Who is willing to participate? European Journal of Political Research, 52(6), 747-772.

\section{SUPPORTING INFORMATION}

Additional supporting information may be found online in the Supporting Information section at the end of the article. 